\title{
Farmers' Perspective on Sociological and Environmental Issues of Urban and Peri-Urban Agriculture: A Case Study from Western and Southern Regions of Sierra Leone
}

\author{
Osman Nabay ${ }^{1}$, Abdul R. Conteh ${ }^{1}$, Alusaine E. Samura ${ }^{1}$, Emmanuel S. Hinckley ${ }^{1} \&$ Mohamed S. Kamara $^{1}$ \\ ${ }^{1}$ Sierra Leone Agricultural Research Institute (SLARI), Njala Agricultural Research Centre (NARC), Freetown, \\ Sierra Leone \\ Correspondence: Osman Nabay, Sierra Leone Agricultural Research Institute (SLARI), Njala Agricultural \\ Research Centre (NARC), Freetown, P.O. Box 540, Sierra Leone. Tel: 232-(76)-818134. E-mail: \\ nabayosman@yahoo.com
}

$\begin{array}{ll}\text { Received: February 3, } 2017 & \text { Accepted: March 22, } 2017 \quad \text { Online Published: June 15, } 2017 \\ \text { doi:10.5539/jas.v9n7p186 } & \text { URL: https://doi.org/10.5539/jas.v9n7p186 }\end{array}$

The research is financed by the Competitive Agricultural Research Grants Scheme (CARGS) of the West and Central African Council on Agricultural Research and Development (CORAF/WECARD).

\begin{abstract}
The paper examined and brought to the fore the typical characteristic of urban and peri-urban farmers in Freetown and Bo communities which serves as major source of supply of agricultural products into the cities' markets. The social and environmental aspect and perception of producers involved in urban and peri-urban agriculture was examined. Descriptive statistics and pictograms were used to analyze and present the data. Results indicate that $56.34 \%$ never went to formal school and mostly dominated by women, showing that farming became the alternative means of livelihood support for those groups. Crops grown are purely influenced by market orientation - demand and cost, as is evident in Gloucester (lettuce, cabbage and spring onions). Potato leaves were commonly grown in almost all communities, reason being that it serves as common/major sauce/vegetable cooked in every household in Sierra Leone. Maize and rice were featured in Ogoo farm - government supervised land set aside purposely for growing crops to supply the city. Findings also revealed that majority of the farmers are resource poor, judging from calculation about their monthly income earning and available household assets and amenities. About $70.4 \%$ of the lands the farmers grow their crops on is leased for production. Except for Gloucester community, when costs of production will be summed, minimal benefit seem to be realized from the farming activities. Even though some of these farmers are engaged in organization, many have limited access to micro financial organization that would probably loan them money to upscale production.
\end{abstract}

Keywords: urban gardening, sociological perspective, environmental perspective, Sierra Leone

\section{Introduction}

Urban and peri-urban agriculture is a common practice benefiting millions of people residing within the cities of Sierra Leone before and after independence. Intensification of urban agricultural activities emerged during the massive rural-urban migration as a result of the civil strife from 1991-2002 (Kanu et al., 2009). At the end of ten-year civil war, a significant proportion of the population who had sought refuge in urban communities decided to remain in those areas in search of jobs with the hope of improving their living conditions. This resulted in an unprecedented increase in urban populations creating high pressures on food supplies, urban facilities and services. The bulk of these refugees were rural migrants with a strong agricultural background. In the absence of regular employment, many of these migrants entered into urban and peri-urban agriculture, cultivating leafy vegetables and marketing fruits and vegetables within and near the urban centers, especially Freetown, the capital city.

Young displaced people especially women, were engaged in the production and marketing of agricultural products as their major source of livelihood. These factors contributed to a significant expansion of urban and peri-urban agriculture as an essential coping strategy for providing the vital augmentation of food stocks (Kanu et al., 2009). Since 2005, in order to mitigate the impending food crisis, the Ministry of Agriculture in Sierra Leone has been 
promoting urban farming under the United Nations Food and Agriculture Organization's Special Project for Food Security. The most commonly cultivated crops are exotic vegetables (cabbage, lettuce, carrots, spring onions, spinach, tomatoes, beans, etc.) and indigenous vegetable crops such as potato leaves, cassava leaves, Krain-Krain (Cochorusclitoris).

Following the identification of research priorities through a scoping study and a validation by stakeholders in the west and central African region, two programs of CORAF/WECARD (Livestock, Fisheries and Aquaculture \& Natural Resources Management) launched a call for concept notes and later calls for proposals on priority themes identified by stakeholders. The evaluation process resulted in approval for funding by the Board of CORAF/WECARD at its regular session in May 2011 in N'Djamena, Chad, for the following proposal: Negative Externalities of Intensification of land cultivated in peri-urban areas: Methods and tools assessment and alternative practices.

Since 2012, CORAF/WECARD has been facilitating the implementation of this competitive project. Its implementation allowed an assessment of the risks related to recycling of organic waste in vegetable production in urban and peri-urban systems. To capitalize the results obtained and ensure a wide dissemination of results, the project received the approval of the donors for a no-cost extension up till September 2016. As a result of this, it was recommended that the project be extended to two new countries, Cameroon (IRAD) and Sierra Leone (SLARI). The report presented here covers the outcomes from a socioeconomic survey of urban and peri-urban farmers implemented in Sierra Leone.

Understanding the socio-economic situation of farmers in urban and peri-urban communities will provide guideline for future intervention strategies that will improve the production of urban food crops and increased income for urban and peri-urban farmers, especially women who are known to be mostly involved in urban and peri-urban agriculture (Van Veenhuizen \& Danso, 2007; Glavan et al., 2015). The primary objective of this survey was to determine the socioeconomic conditions of farmers involved in urban and peri-urban vegetable gardening in Sierra Leone.

\section{Method}

\subsection{Study Areas}

The study was mainly carried out in the Western Urban District, in which the Capital, Freetown, is located; the Western Rural District in which Waterloo the nearest urban center to Freetown, is located; and in Bo (the second largest city in Sierra Leone) in July and August 2016. Figure 1 below shows the study locations.

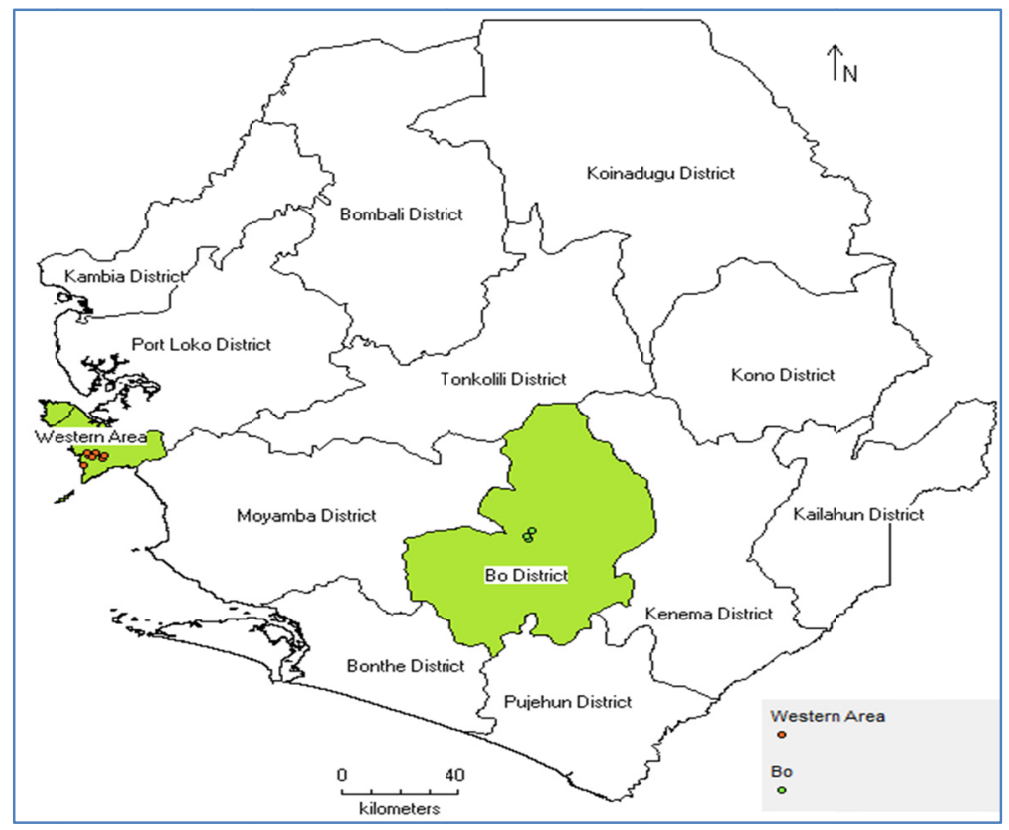

Figure 1. Map of Sierra Leone showing study locations 


\subsection{Sampling}

Listing exercise was carried out to be able to identify the vegetable growing sites and the names of farmers were collected using a data entry form developed to form a data base of major actors. Primary data were collected from a total of 71 urban gardeners. A sample of at least 3 farmer's sites was selected from the survey areas based on the proportion of sites listed: Western Urban, Western Rural and Bo Urban. A purposive sampling was used for the selection of the study area based on the size of land area under cultivation followed by simple random sampling for the site selection (These communities are representatives of urban and peri-urban environs predominant for growing crops that are sold to the cities for consumption) and household interviews.

\subsection{Data Collection}

Primary data were collected from a total of 71 urban gardeners through personal interviews with the use of android devices programmed with Census and Survey Processing System (CSPro 6.3) Computer Assisted Personal Interview (CAPI) data entry application. Data collected included socio-economic characteristics of the respondents, growing space of gardeners, major crops cultivated, irrigation information, inputs (e.g. fertilizer and pesticides), their types, quantity use and sources. The survey also covers perception of crop growers on the impact of their respective growing patterns on their environment. Also the type of livestock and poultry domesticated, household agricultural assets owned and other basic household assets and amenities were captured.

\subsection{Data Analysis}

Data collected from the electronic data capture process was uploaded into the computer and analyzed using the Statistical Analysis System (SAS 9.4), Statistical Package for Social Sciences (SPSS) and Microsoft Office Excel 2007. Socio-demographic characteristics of respondents were summarized by the use of frequency distribution tables and proportion/percentages. The other set of data collected were analyzed using purely descriptive statistics, bar and pie charts were also used during the analysis of other variables.

\section{Results}

\subsection{Socioeconomic Characteristics of Gardeners}

\subsubsection{Age Distribution}

The result showed that $9.86 \%$ of the respondents fall within the age bracket of 30 and below. The remaining $90.14 \%$ were from ages 31 and above, indicating that urban farming is dominated mainly by adults. Out of the $90.14 \%, 22.54 \%$ of these farmers were within the age bracket of $31-45$, forming the more active, energetic and robust group. $67.61 \%$ of the farmers interviewed were within the ages of $46-55$, these are usually the matured and experienced people within the farming cycle (Table 1).

\subsubsection{Gender and Marital Status}

Majority of the respondents were female (70.42\%) while the male respondent accounted for $29.58 \%$. The data also showed that majority (56.34\%) of the farmers were married, $33.8 \%$ were widow/widower and $7.08 \%$ were singles.

\subsubsection{Educational Level}

Majority of the respondents (56.34\%) never went to formal school. Koranic and Junior high school accounted for $11.27 \%$ respectively. Senior high school and university pupils were not attracted to urban and peri-urban agriculture and accounted for $7.04 \%$ and $4.23 \%$ respectively.

\subsubsection{Employment Status}

Majority of the respondent were full time gardeners $(97.18 \%)$ while $2.82 \%$ were engaged in urban agriculture and other non-agricultural activities (Table 1). 
Table 1. Socioeconomic characteristics of urban and peri-urban gardener's

\begin{tabular}{lll}
\hline Characteristics & Frequency & Percent \\
\hline Age & 7 & 9.86 \\
$<=30$ & 16 & 22.54 \\
$31-45$ & $\mathbf{2 5}$ & $\mathbf{3 5 . 2 1}$ \\
$46-55$ & 23 & 32.39 \\
$>=56$ & & \\
\hline Gender & 21 & 29.58 \\
Male & $\mathbf{5 0}$ & $\mathbf{7 0 . 4 2}$ \\
Female & & \\
\hline Marital Status & $\mathbf{4 0}$ & $\mathbf{5 6 . 3 4}$ \\
Married & 5 & 7.04 \\
Single & 24 & 33.8 \\
Widow/Widower & 1 & 1.41 \\
Divorced & 1 & 1.41 \\
Minor (not in age) & & \\
\hline Educational Level & $\mathbf{4 0}$ & $\mathbf{5 6 . 3 4}$ \\
None & 8 & 11.27 \\
Literate/Koranic & 7 & 9.86 \\
Primary & 8 & 11.27 \\
Junior high school & 5 & 7.04 \\
Senior high school & 3 & 4.23 \\
University & $\mathbf{6 9}$ & 2.82 \\
\hline Employment Status & 2 & \\
Employed/Self-employed Full Time & & \\
Employed/Self-employed Part Time & & \\
\hline Fid & & \\
\hline
\end{tabular}

Source: Field survey data, 2016.

\subsection{Average Household Monthly Income of Urban and Peri-Urban Farmers}

In terms of house hold income, farmers in the Western Urban region had higher monthly income than those from either the Western Rural and Bo. 17\% of the respondents in the Western Urban region had monthly income of Le. 900,000 and above while $7 \%$ and $4 \%$ were accounted for in the western rural area and Bo respectively. At lower monthly income level (Le. 101,000 to Le. 300,000) the western urban also accounted for the highest number of farmers (7\%) compared to Bo with $4 \%$ and $(0 \%)$ for Western rural area. Similar trend was observed with monthly income of Le500,000 to Le700,000 however Bo accounted for highest number of respondent (10\%) with monthly incomes between Le. 301,000 to Le. 500,000, followed by Western urban (7\%) and Western rural $3 \%$.

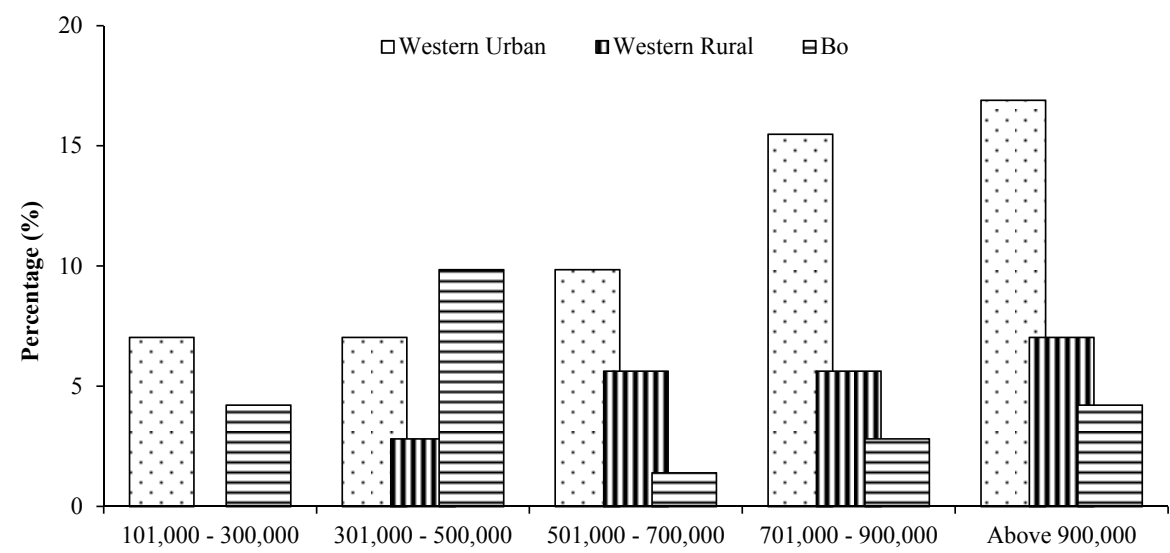

Figure 2. Average household monthly income of urban and peri-urban framers 


\subsection{Memberships in Community Organizations}

Only $40 \%$ of these farmers belong to community organizations. Out of the $40 \%, 26 \%$ belongs to producers group, $22 \%$ farmers association, $18 \%$ women's group $16 \%$ co-operative society, $14 \%$ community/village group and $4 \%$ belongs to microfinance organization (Figure 3).

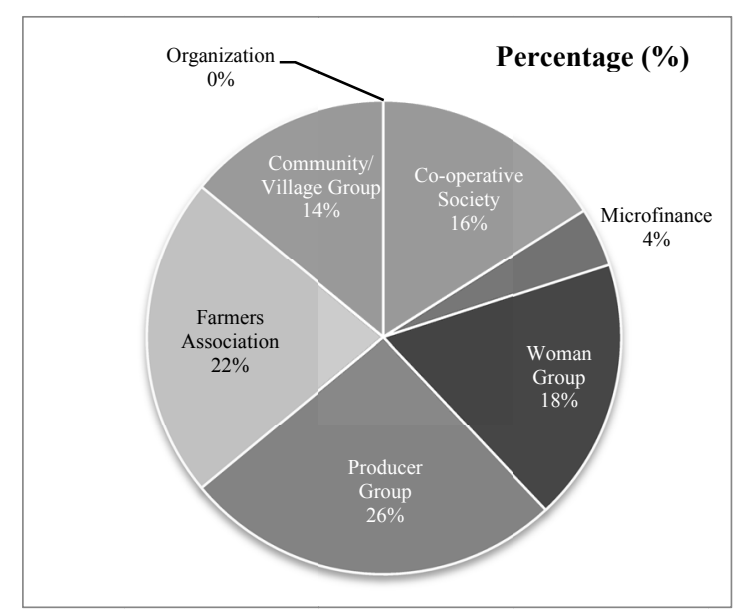

Figure 3. Memberships in community organizations

\subsection{About Gardener Growing Space}

In terms of growing space, $36.6 \%$ of farmers grow crops on public lands away from home and $28.2 \%$ grows on private lands. Public lands here can be defined as land normally belonging to government which is either given to individuals for lease or on free bases (Table 2). On the other hand, Private land are land normally owned by individuals who may have been using or not currently utilizing it and therefore available for rent or sales. Majority of gardeners, $73.2 \%$ pay rent either in cash (70.4\%) or other type of fee (2.8\%) and $26.8 \%$ says they are not paying.

Also, $53.5 \%$ of farmers grow their crops on lowlands or inland valley swamps, while $32.4 \%$ prefer uplands and $14.1 \%$ uses both ecologies. It was evident from (Table 2), $71.8 \%$ of the farmers have be involved in farming exercise for more than 7 years, $18.3 \%$ within $2-4$ years, $8.5 \%$ within $5-7$ years and $1.4 \%$ below 2 years of farming activity. Also, majority (95.8\%) of the farmers reach their growing site on foot, $2.8 \%$ uses public transport and only $1.4 \%$ uses other means of transportation. Many (70.4\%) of the farmers pay rent for lands used for cultivation of their gardens, $26.8 \%$ do not pay rent and $2.8 \%$ pay another type of fee as rent. 
Table 2. Garden growing space

\begin{tabular}{|c|c|c|}
\hline Variables & Frequency & Percent (\%) \\
\hline \multicolumn{3}{|l|}{ Where do you grow your crops } \\
\hline Home garden & 4 & 5.6 \\
\hline Garden plot away from home on private land & 20 & 28.2 \\
\hline Garden plot away from home on public land & 26 & 36.6 \\
\hline $\begin{array}{l}\text { Garden plot away from home on the land of the other owners } \\
\text { (e.g. nearby highways, roadsides?) }\end{array}$ & 21 & 29.6 \\
\hline \multicolumn{3}{|l|}{ Ecology } \\
\hline Lowland/IVS & 38 & 53.5 \\
\hline Upland & 23 & 32.4 \\
\hline Both & 10 & 14.1 \\
\hline \multicolumn{3}{|l|}{ Years of Farming } \\
\hline$<2 \mathrm{yrs}$ & 1 & 1.4 \\
\hline $2-4$ yrs & 13 & 18.3 \\
\hline $5-7$ yrs & 6 & 8.5 \\
\hline$>7 \mathrm{yrs}$ & 51 & 71.8 \\
\hline \multicolumn{3}{|l|}{ Transportation Means to Garden } \\
\hline On foot & 68 & 95.8 \\
\hline By public transport & 2 & 2.8 \\
\hline Other please specify: & 1 & 1.4 \\
\hline \multicolumn{3}{|l|}{ Land Acquisition for Garden work } \\
\hline Yes, I pay a rent & 50 & 70.4 \\
\hline Yes, I pay another type of fee & 2 & 2.8 \\
\hline No & 19 & 26.8 \\
\hline
\end{tabular}

Source: Field survey data, 2016.

\subsection{Percentage Ranking of Cultivated Crops Grown in Targeted Communities}

During the survey it was established that several crops were grown in different communities. However, for the purpose of the survey, three major crops were selected based on their ranking in percentage cultivation in the selected communities. In Freetown communities, 33\% of sweet potato leaves, $27.5 \%$ of krain-krain and $16.5 \%$ of green are being grown. In Gloucester community, $35.3 \%$ of lettuce, $29.4 \%$ of cabbage and $17.7 \%$ of spring onions are being cultivated. At Ogoo Farm, maize appears to top the list $(30.0 \%)$ while rice and okra are equally $(20.0 \%)$ being cultivated. For Bo, the second city of Sierra Leone, okra is the major focus for urban farmers $(22.9 \%)$, followed by potato leaves and maize respectively.

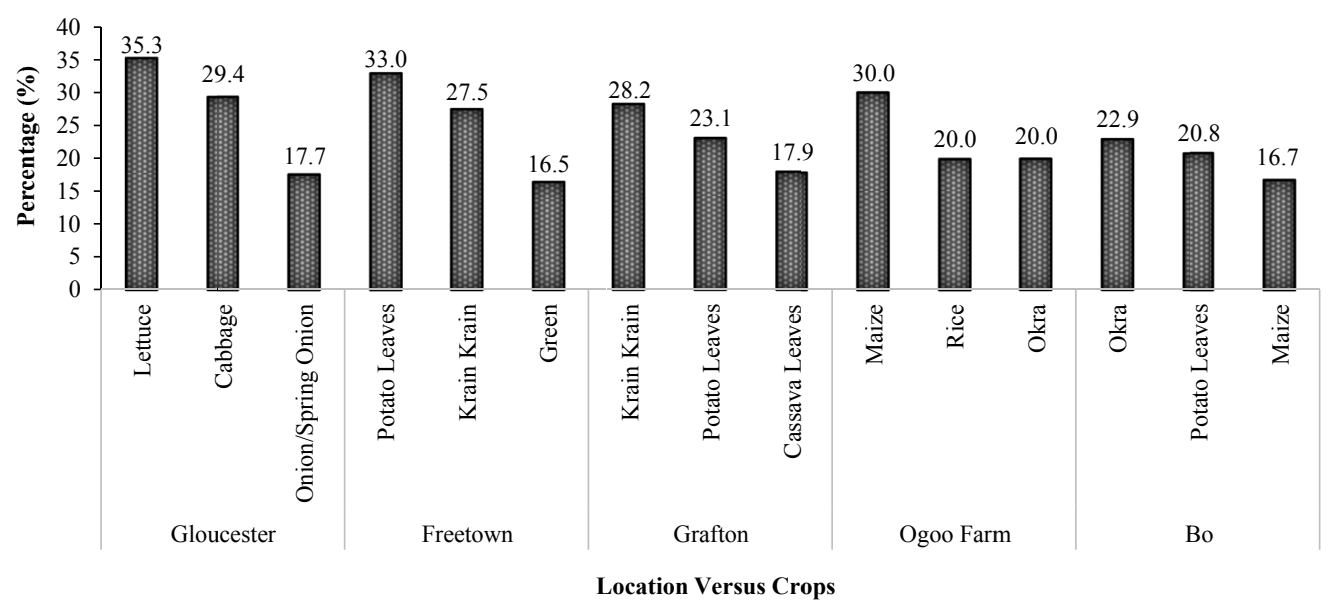

Figure 4. Percentage ranking of cultivated crops grown in targeted communities 


\subsection{Irrigation Practice}

One of the key issues in urban gardening is the growing methods practiced by farmers. Among the urban and peri-urban farmers interviewed, $81.69 \%$ regularly carry out some form of irrigation on their crops with Western Urban communities accounting for the highest number $(45 \%)$ followed by Bo $(21 \%)$ and Western rural (15\%) Only $7.04 \%$ of the respondents irrigate their crop when they think it necessary and $11.27 \%$ don't irrigate at all. Those who don't irrigate consist of cereal producers while those that irrigate constitute mainly of vegetable growers (Figure 5).

๑Western Urban 曰Western Rural 曰Bo

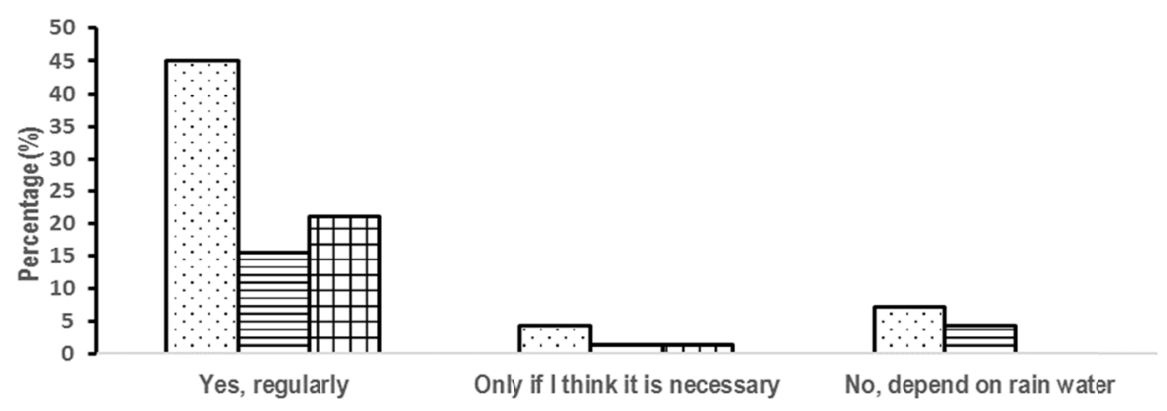

Figure 5. Irrigation practices

\subsection{Source of Irrigated Water}

Generally, $58.73 \%$ of the respondents irrigate their crops through running water, $38.10 \%$ use water wells which may either be a shallow or deep. 3.17\% use tap water obtained from their homes. Respondent in the western urban areas account for $22.22 \%$ of those using running water, Bo accounted for $20.63 \%$ and Western Rural area $15.87 \%$. The western urban area constituted majority $(33.33 \%)$ of the respondents using well water as a source of irrigation (Figure 6).

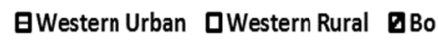

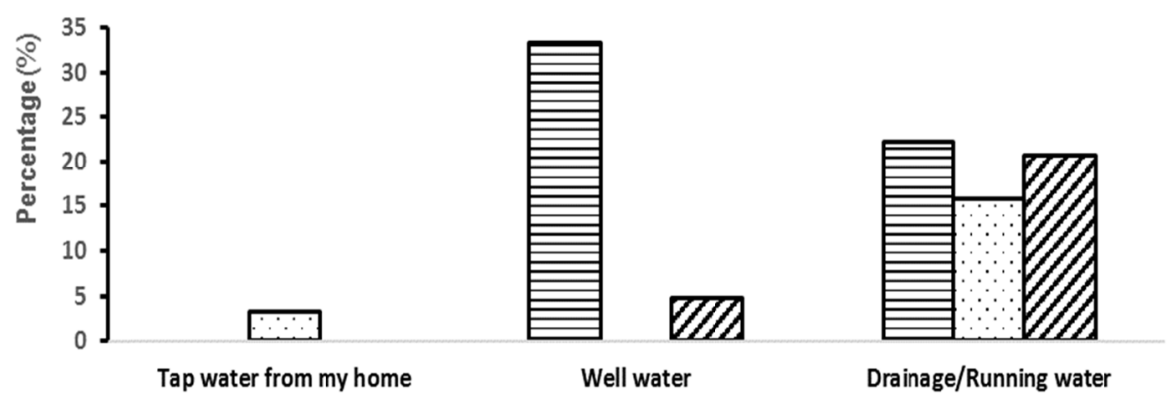

Figure 6. Sources of irrigation water

\subsection{Application of Organic Manure}

Most (about 62\%) of the urban and peri-urban farmers interviewed apply organic manure on their gardens and $38.03 \%$ do not apply. Majority uses excreta from domestic animals (65.91\%), 50\% urban compost, 45.45\% crop residue, $20.45 \%$ green manure and $13.64 \%$ cattle dung (Table 3). Most (61.36\%) of the respondent apply less then $150 \mathrm{~kg}$ per acre, $22.73 \%$ apply range within $150-300 \mathrm{~kg} /$ acre and $15.91 \%$ above $300 \mathrm{~kg} / \mathrm{acre}$. However $81.81 \%$ of the farmers apply during pre-planting and $18.18 \%$ apply during early post planting. 
Table 3. Application of organic manure

\begin{tabular}{|c|c|c|}
\hline Variables & Frequency & Percent \\
\hline \multicolumn{3}{|l|}{ Do you apply organic manure } \\
\hline Yes & 44 & 61.97 \\
\hline No & 27 & 38.03 \\
\hline \multicolumn{3}{|l|}{ Type of Organic Manure use } \\
\hline Cattle Dung & 6 & 13.64 \\
\hline Urban Compost & 22 & 50 \\
\hline Crop Residue & 20 & 45.45 \\
\hline Excretion from other animals & 29 & 65.91 \\
\hline Green Manure & 9 & 20.45 \\
\hline \multicolumn{3}{|l|}{ Quantity of compost per acre } \\
\hline$<150 \mathrm{~kg}$ & 27 & 61.36 \\
\hline $150-300 \mathrm{~kg}$ & 10 & 22.73 \\
\hline Above $300 \mathrm{~kg}$ & 7 & 15.91 \\
\hline \multicolumn{3}{|l|}{ Application Time } \\
\hline Pre Planting & 36 & 81.82 \\
\hline Early Post Planting (2 weeks) & 8 & 18.18 \\
\hline
\end{tabular}

Source: Field survey data, 2016.

\subsection{Source of Organic Manure across Locations}

Western Urban gardeners receive their organic manure from all the 3 sources and they are the highest users as opposed to Bo District farmers who use only the two of those sources (Figure 7).

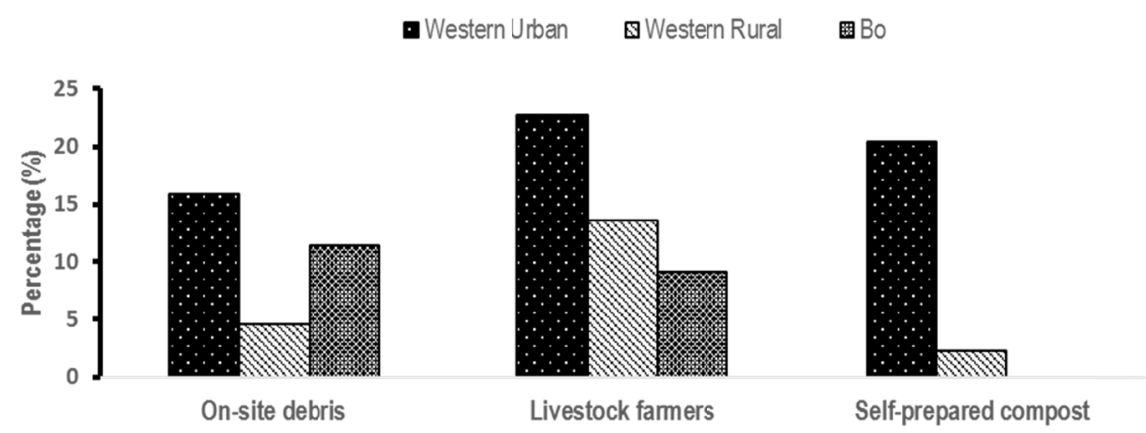

Figure 7. Sources of organic manure

\subsection{Application of Inorganic Fertilizer}

It was interesting to note that most of these urban farmers are also using mineral fertilizer on their vegetable gardens in addition to the organic manure. More than $90 \%$ of those interviewed claimed to be using fertilizer (Table 4). However, most of these farmers use less than $150 \mathrm{~kg} /$ acre by mostly broadcasting the fertilizer on their gardens about two weeks after planting. 
Table 4. Application of mineral fertilizer

\begin{tabular}{lll}
\hline Variables & Frequency & Percent \\
\hline Do you apply mineral fertilizer? & $\mathbf{6 6}$ & $\mathbf{9 2 . 9 6}$ \\
Yes & 5 & 7.04 \\
No & 53 & $\mathbf{8 0 . 3}$ \\
\hdashline Quantity of Fertilizer Per Acre & 10 & 15.15 \\
$<150 \mathrm{~kg}$ & 3 & 4.55 \\
$150-300 \mathrm{~kg}$ & & \\
Above $300 \mathrm{~kg}$ & 56 & $\mathbf{8 4 . 8 5}$ \\
\hdashline Method of Fertilizer Application & 7 & 10.61 \\
Broadcasting & 3 & 4.55 \\
Ring Method & & \\
Side Dressing & 3 & 4.55 \\
\hline Application Time & 62 & $\mathbf{9 3 . 9 4}$ \\
Pre planting & 1 & 1.52 \\
Early Post Planting (2 weeks) & & \\
Late Post Planting & 61 & $\mathbf{9 2 . 4 2}$ \\
\hline Source of Fertilizer & 2 & 3.03 \\
Market & 3 & 4.55 \\
MAFFS & & \\
Other farmers & & \\
\hline
\end{tabular}

Source: Field survey data, 2016.

\subsection{Type(s) of Chemical Fertilizer Commonly Used}

From figure 8, farmers in Freetown urban communities are highest in percentages in the use of both NPK and Urea fertilizers when compared to Bo and Freetown rural. This is as a result of their exposure to agriculture through the mass media and access to input (fertilizer) in the market. Bo is second in the use of Urea and Western Rural is the only area that uses Murate of Potash.

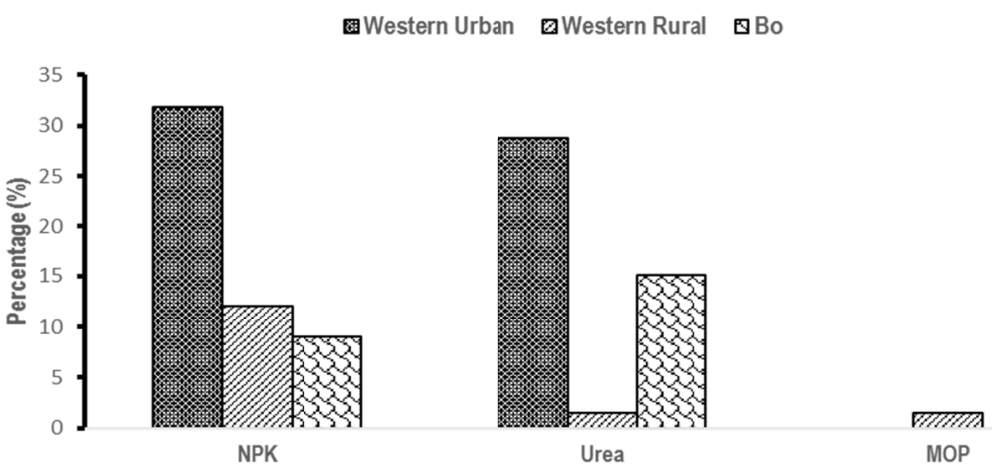

Figure 8. Type(s) of chemical fertilizer commonly used

\subsection{Types of Pesticides Application}

From Table 5, about $57.75 \%$ uses pesticides on their crops during the growing season and the rest do not. The most common pesticide used was insecticides and no one is using either herbicides or fungicides. $60.98 \%$ farmer indicated that of their source pesticide was from the market. $26.83 \%$ of the respondent got their pesticides from other farmers and only $4.88 \%$ access it from Ministry of Agriculture, Forestry and Food security. 
Table 5. Application of pesticides

\begin{tabular}{lll}
\hline Variables & Frequency & Percent \\
\hline Do you apply pesticides on crops & & \\
Yes & 41 & $\mathbf{5 7 . 7 5}$ \\
No & 30 & 42.25 \\
\hline Type of pesticide commonly used & & $\mathbf{9 2 . 6 8}$ \\
Insecticide & 38 & 0 \\
Herbicide & 0 & 0 \\
Fungicide & 0 & 7.32 \\
Others/Cannot specify & 3 & \\
\hdashline Source of Pesticides & & $\mathbf{6 0 . 9 8}$ \\
Market & $\mathbf{2 5}$ & 7.32 \\
NGO & 3 & 4.88 \\
MAFFS & 2 & 26.82 \\
Other farmers & 11 & \\
\hline
\end{tabular}

Source: Field survey data, 2016.

\subsection{Application of Agro-Chemicals across Locations}

Insecticide application was the most common agro-chemical used in all the locations sampled. Out of the total number of respondents sampled, the western area had the highest users $(60.98 \%)$ followed by Bo $(19.51 \%)$ and western rural had $12.2 \%$. No herbicide or fungicide was applied in all location. $7.32 \%$ used chemical that they could not identify (Figure 9).

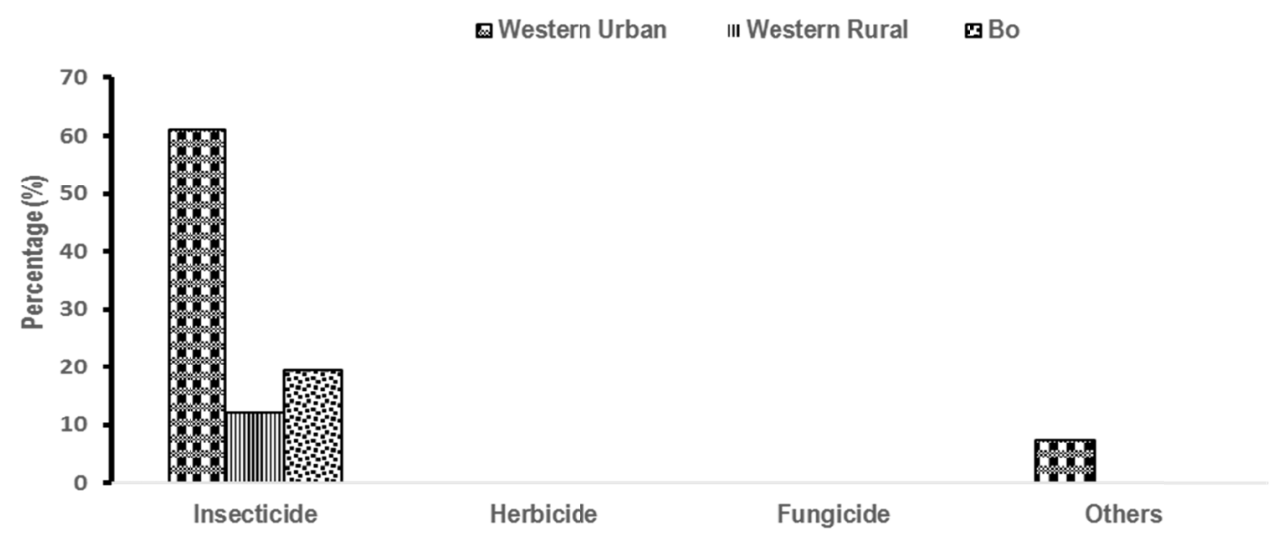

Figure 9. Type(s) of agro-chemicals commonly used

\subsection{Perception of Impact of Growing Crops on the Environment}

Majority (66.2\%), very strongly disagree with the statement that, people who grow their own food lack the right skills to produce vegetables, therefore they contribute significantly to environmental pollution. $25.35 \%$ of the farmers were not aware of any environmental pollution arising from cultivating crops. $8.45 \%$ agreed that their activities were causing environmental pollution. $81.69 \%$ strongly disagreed that land area for cultivation was increasing. $12.68 \%$ could not tell whether land area was increasing or decreasing while 5.63 perceived that land area for cultivation was increasing that land area for cultivation is increasing.

The scarcity of water in the dry season and its effect on crop production was examined. $30.99 \%$ of the respondents strongly disagreed to this statement. $26.76 \%$ could neither agree nor disagree while $42.25 \%$ strongly agree. In terms of food safety, 15.49 strongly disagreed that organic or biodynamic agriculture was the only proper way of growing healthy crops. 43.34 could neither agree nor disagree while $40.85 \%$ of the respondent strongly agreed to this statement. The general appearance of the environment with the practice of agriculture in the urban and peri-urban areas was also examined. The results show that $56.34 \%$ of the respondent strongly 
disagreed that the construction of bed and other accompanying facilities disfigure the environment. $36.62 \%$ could neither agree nor disagree while $7.04 \%$ strongly agree to this statement. A percentage $(5.63 \%)$ of the respondents strongly disagreed that social interaction within the farm strengthen the integration of people in the community. $23.94 \%$ of the respondents could not agree or disagree to this statement, however majority of the respondent $(70.42 \%)$ strongly agreed to this statement and $56.34 \%$ land area for cultivation is increasing overtime and with their crop-beds and accompanying facilities allotment holders disfigure the appearance of the environment respectively (Figure 10).

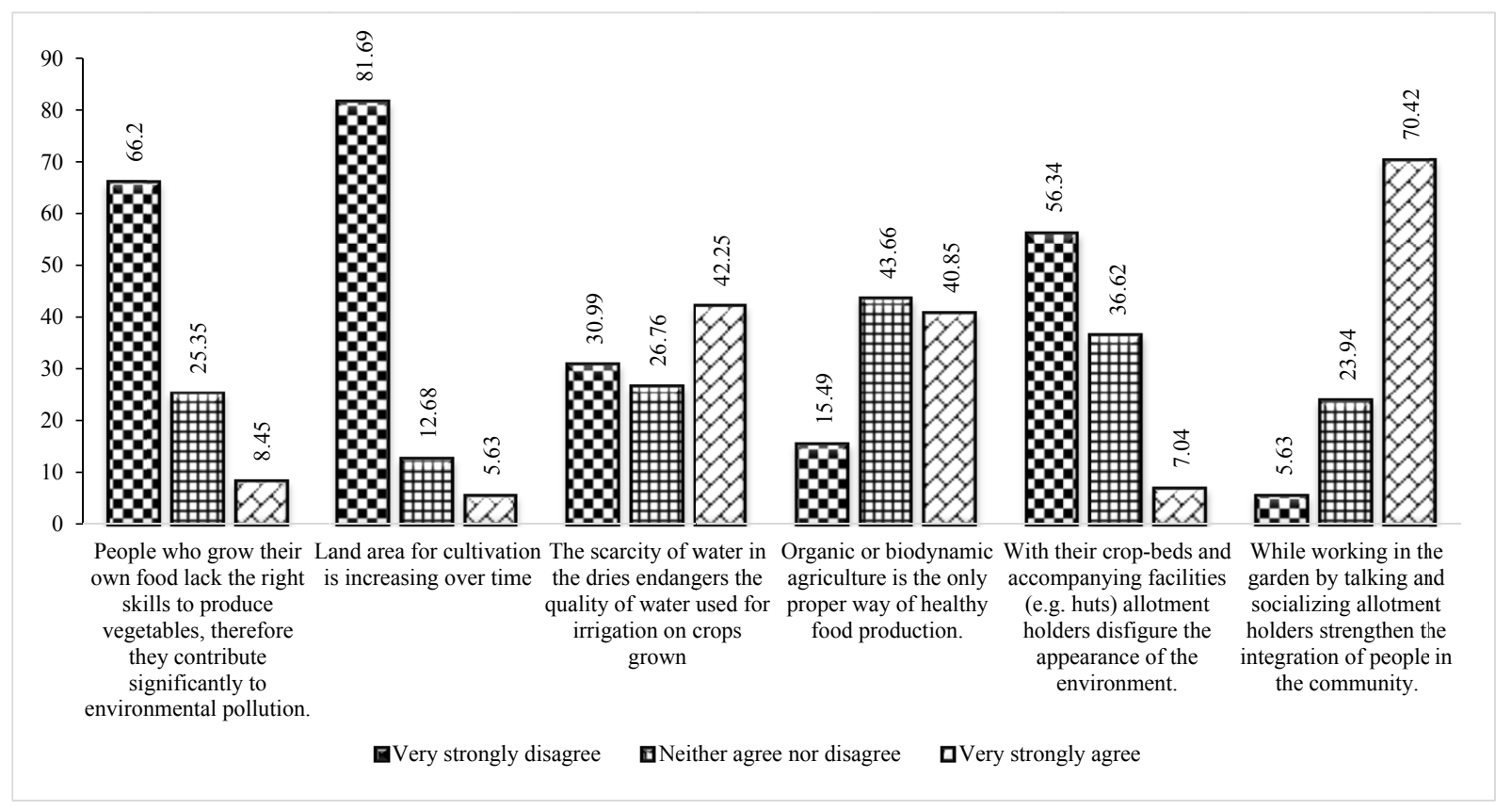

Figure 10. Perception of impact of growing crops on the environment

\subsection{Household Livestock and Poultry Services for Gardeners}

Few farmers interviewed had livestock. $8.82 \%$ owned bulls/cows, while $5.88 \%, 11.76 \%, 5.88 \%$ and $2.94 \%$ had sheep, goats, pigs and rabbits respectively. Majority of the respondents (91.18\%) own chicken and $32.35 \%$ own duck. Chicken and duck have the lowest market value in Sierra Leone. This implies that farmers do not benefit from integrating livestock and crop production and may have to resort to buying organic manure from other sources. Again the level of poverty of these gardeners is clearly shown here. Rabbit farming is uncommon while pig farming and consumption is constrained by religious beliefs.

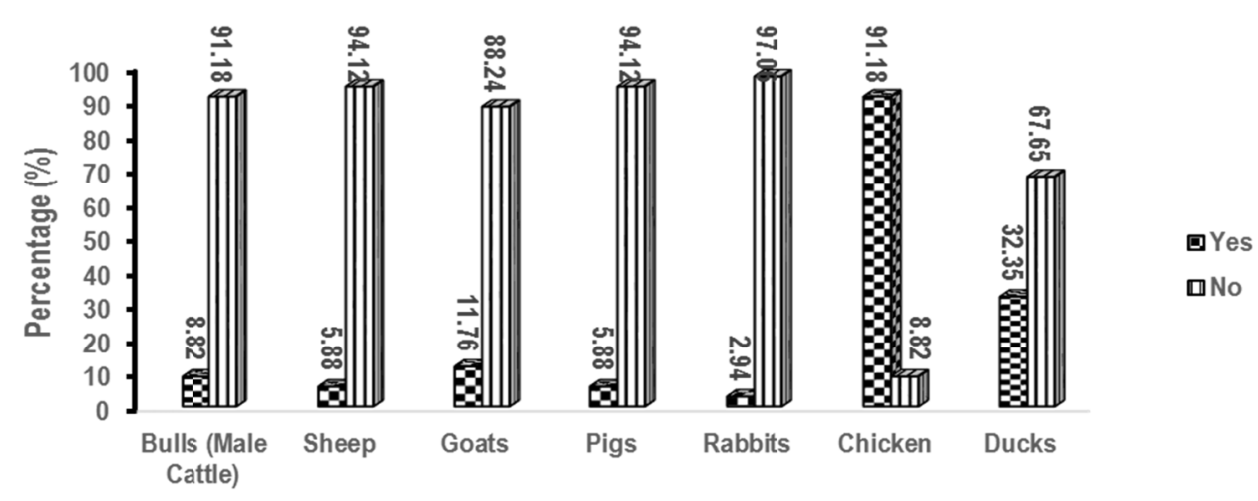

Figure 11. Household livestock and poultry services for gardeners 


\subsection{Household Agricultural Assets}

Figure 12 displays the inventory of household agricultural assets the farmers owned. From the data presented, there is nothing to write home about tools. In terms of mean value of tools owned by the farmers, Hand fork is highest (5.2), while insecticide sprayer (1.25) is the lowest. The total mean value of all agricultural asset falls within 2.

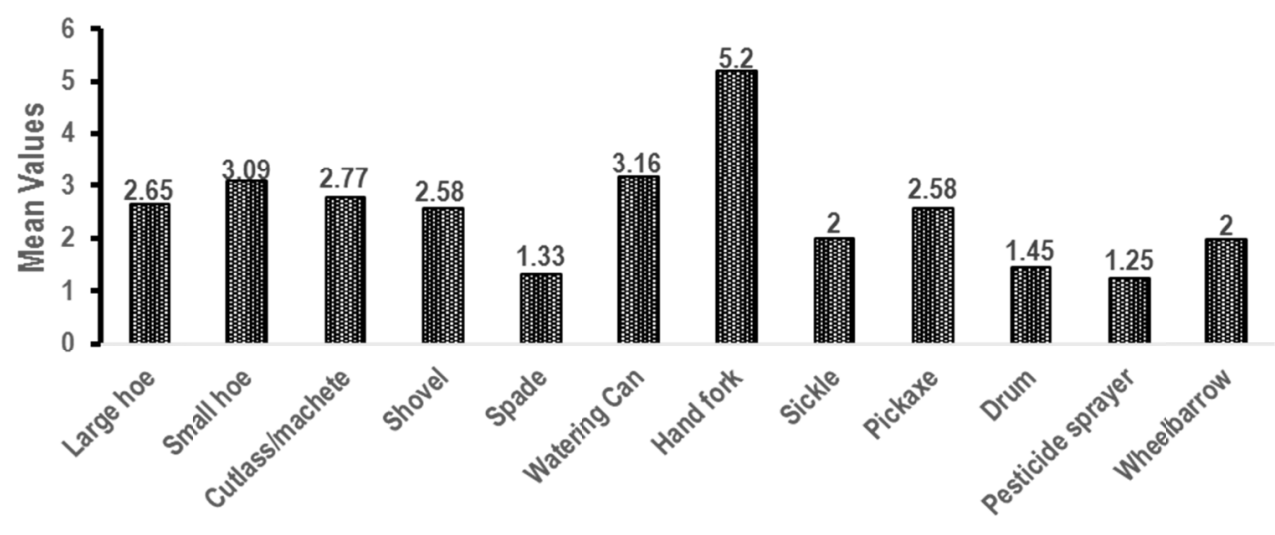

Figure 12. Household agricultural assets inventory for gardeners

\subsection{Household Assets of Gardeners}

From Figure 13, in terms of possession of House hold assets, only 7.04 per cent owns a Bicycle, 11.27 per cent owns a generator, $8.45 \%$ have truck/car/motorcycle and $19.72 \%$ owns an electric fan. This data clearly shows the level of poverty the gardeners are battling with. However (85.92\%) have mobile phones and $(63.38 \%)$ also possess a radio or cassette player. The high percentage communication gargets (mobile phone and radio) which the farmers possess will to a greater extent assist them to access market and other agricultural information that will enable them improve their farm practice.

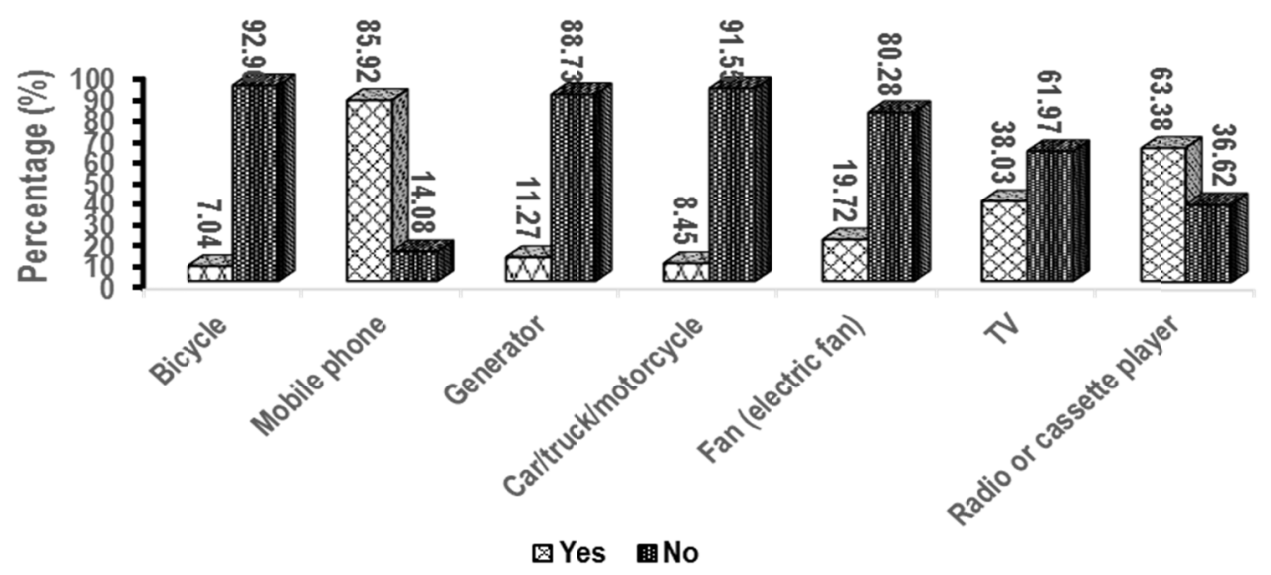

Figure 13. Household assets of gardeners

\subsection{Household (HH) Amenities of Gardeners}

Respondents with houses made up of concrete or tile floors constitute the highest proportion (69.01\%), followed by those $(26.76 \%)$ with mud houses. For roofing materials, farmers with corrugated iron roof had the highest percentage $(88.73 \%$ ) while those with thatch materials make up the lowest $2.82 \%$. This may be attributed to the proximity and access to building materials in the cities. $47.89 \%$ of the respondent had houses that are made with of cement bricks while $29.58 \%$ had Mud walls/mud bricks/wattle. 
The dominant sources of household materials for cooking was charcoal $(80.28 \%)$ followed by wood $(19.72 \%)$. There is no evidence of the farmers using either gas $(0.00 \%)$ or kerosene $(0.00 \%)$ This survey is an eye opener to the way/level to which farm lands are being degenerated into deforestation that is tantamount to climate change and global warming.

About $80.28 \%$ of the respondents uses pit latrine, $4.23 \%$ uses flush inside and $9.86 \%$ uses flush outside the houses. Up to 2.82 are still using bush or river beds. This situation possesses a serious threat to food safety resulting from run-off into farmland which is eventually used as a source of water for irrigating crops. Up to 56.34 per cent uses tap water, 25.35 per cent uses ordinary well and 18.31 per cent use mechanical well. Sanitation becomes a key concern here for household health and welfare (Table 6).

Table 6. Household (HH) amenities of gardeners

\begin{tabular}{|c|c|c|}
\hline Variables & Frequency & Percent \\
\hline \multicolumn{3}{|l|}{ HH dwelling material of the floor } \\
\hline Earth/Mud & 19 & 26.76 \\
\hline Wood & 2 & 2.82 \\
\hline Stone/Gravels & 1 & 1.41 \\
\hline Cement/Concrete/Tiles & 49 & 69.01 \\
\hline \multicolumn{3}{|l|}{$H H$ dwelling material of the roof } \\
\hline Thatch (grass/straw/palm fronds) & 2 & 2.82 \\
\hline Wood & 1 & 1.41 \\
\hline Corrugated iron (zinc/tin) & 63 & 88.73 \\
\hline Tarpaulin (plastic sheets) & 4 & 5.63 \\
\hline Cement/Concrete/Tiles & 1 & 1.41 \\
\hline \multicolumn{3}{|l|}{$H H d$ welling material of the walls } \\
\hline Mud/Mud Bricks/Wattle & 21 & 29.58 \\
\hline Wood & 3 & 4.23 \\
\hline Corrugated Iron (zinc/tin); & 12 & 16.9 \\
\hline Stone/Burnt Bricks & 1 & 1.41 \\
\hline Cement Bricks & 34 & 47.89 \\
\hline \multicolumn{3}{|l|}{ HH source of cooking materials } \\
\hline Wood & 14 & 19.72 \\
\hline Charcoal & 57 & 80.28 \\
\hline Gas & 0 & 0 \\
\hline Kerosene & 0 & 0 \\
\hline Other & 0 & 0 \\
\hline \multicolumn{3}{|l|}{ Type of HH toilet facility } \\
\hline VIP & 1 & 1.41 \\
\hline Flushed inside & 3 & 4.23 \\
\hline Flushed outside & 7 & 9.86 \\
\hline Pit & 57 & 80.28 \\
\hline Bucket & 0 & 0 \\
\hline Bush/River Bed & 2 & 2.82 \\
\hline Other (specify) & 1 & 1.41 \\
\hline \multicolumn{3}{|l|}{ Source of HH drinking water } \\
\hline Tap & 40 & 56.34 \\
\hline Mechanical Well & 13 & 18.31 \\
\hline Ordinary Well & 18 & 25.35 \\
\hline Spring & 0 & 0 \\
\hline River/Stream/Pond & 0 & 0 \\
\hline
\end{tabular}

Source: Field survey data, 2016. 


\section{Discussion}

The study examines the typical characteristic of urban and peri-urban farmers in Freetown and Bo communities using descriptive statistics and pictograms. The social and environmental aspect and perception of producers involved in urban and peri-urban agriculture is also examined. Urban and Peri-Urban Agriculture is a common practice benefiting millions of people residing within the cities of Sierra Leone before and after independence. Intensification of urban agricultural activities emerged during the massive rural-urban migration as a result of the civil strife from 1991-2002 (Kanu et al., 2009).

The first one pertains to the socio-economic profile of urban gardeners in Freetown and Bo communities indicates that,majority of the respondent were full time gardeners in urban and peri-urban areas and dominated mainly by adults who are usually the matured and experienced people within the farming cycle.Majority of those were female and married. This implies that, married women were more attracted to urban and peri-urban agriculture probably due to domestic responsibilities unlike single people who may have alternative sources of income.Most of those never went to formal school. One can deduce from this result that the enterprise is serving as an alternative profession and means of livelihood for non-school goers. This is in consonance with the research findings of (Kanu et al., 2009; Winnebah et al., 2004).

Only $40 \%$ of these farmers belong to community organizations. This may imply that only few of these farmers have organized forum where they can likely discuss issues pertaining their farming activities, their welfares, challenges and ways of improving on emerging challenges. Of those who belong to community organizations, about $65 \%$ of them belong to either farmer associations, producer groups or other women's groups (Figure 3).

In terms of house hold income, farmers in the Western Urban region had higher monthly income than those from either the Western Rural and Bo.This result is an indication of the higher demand and price for vegetables produced in the western urban region (Figure 2). During the survey, it is worth noting that the farmers find it difficult to comprehensively or accurately calculate their actual earning as income within a month. Monies obtained from other family members and friends as hand-out were hardly accounted for or tracked. It can also be seen (Figure 2) that more than $28 \%$ of the growers interviewed earn over 900,000 per month (roughly US $\$ 150$ ).

The second component which relates to gardeners growing space reveals that, urban farmers are well informed about the productive potential of lowland in terms of agro- nutrient fertility as opposed to uplands. This is also in support of government land policies. All lowlands in urban cities especially in Freetown is owned by government, therefore they are available for crop production to supply the cities. Because the lands in the urban cities are reducing drastically as a result of massive constructions of houses and other activities, many gardeners have resorted to managing the limited upland and adjacent lowlands alternatively for both rainy and dry seasons respectively.

It was evident from Table 2 that, $71.8 \%$ of the farmers have been involved in farming exercise for more than 7 years, meaning it has been a source of livelihood activities and fetching them dividend. Also, majority (95.8\%) of the farmers reach their growing site on foot, probably as a result of the proximity or means of securing transport fare to reach their farms. Many (70.4\%) of the farmers pay rent for lands used for cultivation of their gardens, implying that farmer are resource poor in term of acquisition of lands. Some of these lands may belong to close friends.

The other issue captured is the growing method. During the survey it was established that several crops were grown in different communities. However, for the purpose of the survey, three major crops were selected based on their ranking in percentage cultivation in the selected communities. In Freetown communities, sweet potato leaves $(33 \%)$ rank highest in cultivation. In Gloucester community, lettuce $(35.3 \%)$ rank highest being grown. At Ogoo Farm, maize appears to top the list (30.0\%). For Bo, the second city of Sierra Leone, okra is the major focus for urban farmers $(22.9 \%)$. With regards the pattern of crops cultivated by these urban farmers, they are gradually shifting away from the traditional pattern of crops being cultivated which was more consumption focus to a more economically viable level that make quick returns (Figure 4).

Another key issue highlighted in the survey is the irrigation methods practiced by farmers. Among the urban and peri-urban farmers interviewed, majority of respondent regularly carry out some form of irrigation on their crops.Those that irrigate constitute mainly of vegetable growers (Figure 5). Generally, majority (58.73\%) of those respondents irrigate their crops through running water (Figure 6).

Also result shows that most (about 62\%) of the urban and peri-urban farmers interviewed apply organic manure on their gardens. The most frequently used organic manures by the farmers are excreta from domestic animals, crop residues, and domestic waste (Table 3). Despite the large number respondents who apply organic manure, 
the quantities applied are generally low with most of them applying less than $150 \mathrm{~kg} / \mathrm{ha}$. This can be associated to the level of knowledge and awareness of farmers about the use of crop residue in cultivation. About $81.81 \%$ of the farmers apply organic manure at pre-planting and $18.18 \%$ apply during early post planting. More than $90 \%$ of those interviewed claimed to be using fertilizer (Table 4). However, most of these farmers use less than 150 $\mathrm{kg} /$ acre by mostly broadcasting the fertilizer on their gardens about two weeks after planting.

Farmers in Freetown urban communities are highest in percentages in the use of both NPK and Urea fertilizers when compared to Bo and Freetown rural. This may be related to the easy access to agricultural information through media and input (fertilizer) availability in the market. Bo is prominent in the use of Urea and only western rural communities uses Murate of Potash.

Except for mobile phones (85.92\%) and radio or cassette player (63.38\%), all other household amenities which the farmers possess are in low quantities. This is so especially with farming tools.

Although $88.73 \%$ of respondents dwell in houses with corrugated iron roof and $69.01 \%$ of their houses with concrete or tiles floors, majority $80.28 \%$ of the farmers still uses charcoal as cooking materials. About $80.28 \%$ of house hold uses pit latrine, $4.23 \%$ uses inside flush (self-contain) and $9.86 \%$ uses flush outside the houses. This is showcasing the real living conditions of these urban and peri-urban farmers.

\section{Conclusion}

It can be concluded from the study that most of the farmers engaged in urban and peri-urban farming in Sierra Leone were illiterate married women between the ages of 46 to 55 years. Farmers in the western urban areas generated higher income compared to other locations. $40 \%$ of the farmers belonged to organisations and utilised government land for cultivation of crops for which rent is paid. However most of the farmers had used their own land or family land. The preference of crops grown was determined by the prevailing market opportunities. The source of water was mainly running water. Most of the farmers combined the use of organic and inorganic fertilizer. The dominant organic manure used was crop residue which NPK and urea was the most common inorganic fertilizer. Agro chemical use was common but was restricted to insecticides.

Farmers generally perceived that their activities had no negative environmental consequence and that the crops produced were safe for consumption. Most of the farmers were resource poor and had limited access to land. Most farmers did not own livestock, appropriate tools and house household assets. Despite having corrugated zinc sheets in their roof, most of houses had pit latrines which posed a threat to food safety.

As a recommendation, there should be a lot of government investment in the area of food crop production especially around the cities which is often in high demand for it. This could be done through loan to urban crop growers and subsidies on agricultural inputs. Because the farmer's uses input such as fertilizers and other agro-chemical regularly, there is need for the testing of the soils and the cultivated plants for abiotic and biotic negative externalities and there is also need for training in the use of those chemicals. Also animal dropping mixed urea have been use as manure on plants over the years. Concern should also be given to some farmer growing crops in urban compost (Kington and Kissy refuse dump site). At domestic level, policy makers are require also to come in and arrest the situation of wood and charcoal burning which rapidly reducing the forest and making the soil bared tantamount to erosion, etc. If there are laws already binding this exercise, it needs to be reinforced or robust to curtail this looming health hazards. The acquisition of land for urban farming is still very challenging and the little available is also under serious threats under rapid estate development.

\section{References}

Anonymous. (2010). Benefits of School Gardens. University of Florida, Environmental Horticulture Department.

Barry, S. G., \& Foerster, J. W. (2007). Seeking Environmental Stewardship: One Garden at a Time. Journal of Extension, 45(1).

Bellwood-Howard, I., Häring, V., Karg, H., Roessler, R., Schlesinger, J., \& Shakya, M. (2015). Characteristics of Urban and Peri-urban Agriculture in West Africa: Results of an Exploratory Survey Conducted in Tamale, Ghana, and Ouagadougou, Burkina Faso. IWMI Working Paper 163. International Water Management Institute. https://doi.org/10.5337/2015.214

Blair, D. (2009). The child in the garden: An evaluative review of the benefits of school gardening. The Journal of Environmental Education, 40(2), 15-38. https://doi.org/10.3200/JOEE.40.2.15-38

Bradley, J. C., \& Skelly, S. M. (2000). The Importance of School Gardens as Perceived by Florida Elementary School Teachers. Hort. Technology, 10(1), 229-231. Retrieved from http://horttech.ashspublications.org/ content/10/1/229.full.pdf 
Glavan, M., Pintar, M., Černič-Istenič, M., Sali, G., Corsi, S., Mazzocchi, C., ... Wascher, D. (2015). Lesson learned on urban gardening phenomenon.

Guerra, F., Trevizam, A. R., Muraoka, T., Marcante, N. C., \&Canniatti-Brazaca, S. G. (2012). Heavy metals in vegetables and potential risk for human health.

Hoogh, I., Osiro, A., Wiegers, E., Fornah, D., Sawi, M., \& Rhodes, E. (2011). Improving Nutrition through Agriculture: Challenges and Opportunities. An example from Sierra Leone. Retrieved from http://www.slari.gov.sl/reach.pd

Kanu, S., Tengbe, P., Winnebah, T. R., \& Konneh, P. (January, 2009). Promoting urban agriculture in post-conflict greater Freetown area, Sierra Leone. Urban Agriculture Magazine, 21, 19-21. Retrieved from http://www.ruaf.org/sites/default/files/UAM21\%20p.19-21.pd

Okoth, P. F., Nambiro, E., Kibe, P., Njoroge, S., Macharia, R., Kihara, J., \& Huising, J. (2012). A practical guide for collecting farmers' socio-economic and agronomic data: An AfSIS Project field protocol. International Center for Tropical Agriculture. Retrieved from http://hdl.handle.net/10568/49625

Van Veenhuizen, R., \& Danso, G. (2007). Profitability and sustainability of urban and peri-urban agriculture (Vol. 19). Food \& Agriculture Org. Retrieved from ftp://ftp.fao.org/docrep/fao/010/a1471e/a1471e00.pdf

Winnebah, T. R. A. (2007). Urban agriculture: An inventory of Greater Freetown Area (GFA). RUAF Foundation, Republic of Sierra Leone and IWMI, A FUPAP Exploratory Studies Monograph, Freetown, Sierra Leone.

Winnebah, T. R. A., \& Cofie, O. (2007). Cityscape: Freetown: Farms after a War. Urban Planet: A World Watch Institute State of the World Report (Chapter 3).

Winnebah, T. R. A., Sandy-Magao, C., Barrie, I. S., Domingo, J., Koroma, A. I., Momo, J. D. J., ... Hanson. (2004). Gender and urban agriculture: a case study of three communities in greater Freetown, Sierra Leone. Paper presented at RUAF/Urban harvest women feeding cities workshop on gender mainstreaming in urban food production and food security, held in Accra, Ghana.

\section{Copyrights}

Copyright for this article is retained by the author(s), with first publication rights granted to the journal.

This is an open-access article distributed under the terms and conditions of the Creative Commons Attribution license (http://creativecommons.org/licenses/by/4.0/). 